\title{
RADIOCARBON DATING OF INTERCOMPARISON SAMPLES AT THE ZAGREB RADIOCARBON LABORATORY
}

\author{
NADA HORVATINČIĆ, DUŠAN SRDOČ, BOGOMIL OBELIĆ \\ and \\ INES KRAJCAR BRONIĆ
}

Rudjer Bošković Institute, PO Box 1016, 41001 Zagreb, Yugoslavia

\begin{abstract}
The Radiocarbon and Tritium Laboratory of the Rudjer Bošković Institute, Zagreb, participated in the International Collaborative Study (ICS) in all three stages. All measurements were made by proportional counting of methane. We present here a statistical analysis of our results. A comparison with the mean or median values of reported ICS values showed that our results are generally slightly younger.
\end{abstract}

\section{INTRODUCTION}

This is the first time that our Radiocarbon Laboratory has taken part in a Radiocarbon Intercomparison Study. Some intercomparisons were made between our laboratory and those of Uppsala, Hannover, Groningen, Seattle, Lyon and Stockholm, but these were only comparisons of single samples and not systematic studies, such as this one organized by the Department of Statistics, University of Glasgow.

We started routine sample processing and measurement in the Zagreb Radiocarbon Laboratory in 1970 and dated ca 2200 samples. All measurements were made by gas proportional counting of methane. Sample pretreatment, combustion and the counter technique were essentially the same as described in Srdoč et al (1971) supplemented by computerized data processing (Obelić \& Planinić 1977; Obelić 1980, 1989). We use NBS oxalic acid (I) as the modern standard and anthracite, Carrara marble and old $\mathrm{CH}_{4}$ from a borehole as the background standards. We also used the same gas for dilution in case of an insufficient amount of sample material. The oxalic acid count rate is $(27.5 \pm 0.2) \mathrm{min}^{-1}$, and the background count rate is $(5.75 \pm 0.12) \mathrm{min}^{-1}$.

We calculated the ages according to the conventions recommended by Stuiver and Polach (1977). We calculated the error of each result according to the law for the propagation of error and the weighted mean value of several measurements; the standard deviation was calculated according to standard formulae:

$$
\begin{aligned}
& \mathrm{t}_{\text {mean }}=\frac{\mathrm{t}_{\mathrm{i}} /\left(\sigma_{\mathrm{i}}^{2}\right)}{\left(1 / \sigma_{\mathrm{i}}^{2}\right)} \\
& \sigma^{2}=1 /\left[\Sigma\left(1 / \sigma_{\mathrm{i}}^{2}\right)\right]
\end{aligned}
$$

We measured ${ }^{13} \mathrm{C}$ values of the samples at the Jožef Stefan Institute, Ljubljana, Yugoslavia, and applied a fractionation correction.

\section{RESULTS}

The Zagreb Radiocarbon Laboratory participated in all three stages of the International Collaborative Study. Results from Stage 1 should reflect counting statistics only, and those from Stage 2 should introduce sample preparation error. However, gas counting techniques do not reveal any difference between Stages 1 and 2, with respect to chemical preparation of samples. We had to prepare our gases $\left(\mathrm{CO}_{2}, \mathrm{CH}_{4}\right.$, etc) by applying the same method in both cases. In other words, 
Stage 1 did not reflect counting statistics only, as opposed to the users of the LSC technique who received benzene samples for dating. In the case of the gas counting method, both Stages 1 and 2 did include counting and preparation errors.

We discuss the results of measurements of ICS samples from Stages 1 and 2 separately from Stage 3, which introduced the sample pretreatment error.

\section{Stages 1 and 2}

Table 1 presents our results for Stages 1 and 2. The results are compared with the summary statistics for the four distinct samples given in the progress reports (Scott et al 1989).

TABLE 1

Results of sample measurements from Stages 1 and 2 (in yr BP)

\begin{tabular}{|c|c|c|c|c|}
\hline \multirow[b]{2}{*}{$\begin{array}{l}\text { Sample } \\
\text { code }\end{array}$} & \multicolumn{2}{|c|}{ Zagreb results } & \multicolumn{2}{|c|}{ ICS results } \\
\hline & $\begin{array}{l}\text { Single } \\
\text { sample }\end{array}$ & $\begin{array}{l}\text { Duplicates, } \\
\text { mean value }\end{array}$ & Average & $\begin{array}{l}\text { Quartile } \\
\text { range }\end{array}$ \\
\hline $\begin{array}{l}\text { Stage } 1 \\
\text { C carb } 1 \\
\text { L carb } 1\end{array}$ & $\begin{array}{c}14 \pm 50 \\
7 \pm 50\end{array}$ & 10.5 & -66 & -100 \\
\hline $\begin{array}{l}\mathrm{M} \text { carb } 2 \\
\mathrm{~S} \text { carb } 2\end{array}$ & $\begin{array}{l}3700 \pm 60 \\
3290 \pm 60\end{array}$ & 3531 & 3600 & $3570-3670$ \\
\hline $\begin{array}{l}\text { Stage } 2 \\
\mathrm{~J} \text { algal } \\
\mathrm{G} \text { algal }\end{array}$ & $\begin{array}{l}1996 \pm 72 \\
2063 \pm 63\end{array}$ & 2120 & 2120 & $2040-2200$ \\
\hline $\begin{array}{l}\mathrm{T} \text { cell } \\
\mathrm{U} \text { cell }\end{array}$ & $\begin{array}{l}2178 \pm 65 \\
2146 \pm 63\end{array}$ & 2161 & $\begin{array}{l}2250 \\
\text { (equivalen }\end{array}$ & $\begin{array}{l}2160-2370 \\
\left.{ }^{14} \mathrm{C} \text { age } 2180 \mathrm{yr}\right)^{*}\end{array}$ \\
\hline
\end{tabular}

*The absolute date of the wood sample provided by the Belfast dendrochronological laboratory and from which the cellulose was extracted was 241-260 BC. With the calibration data (Pearson et al 1986), these calendar dates would correspond to radiocarbon ages of 2220-2160 years BP, or 2180 years BP on the average.

Figure 1 shows the plot of our data for duplicate pairs together with the ideal line of equality drawn for comparison.

Three pairs of samples from Stages 1 and 2 are very close to the ideal line of equality (Fig 1). The single values of samples in these pairs lie within 10 error, thus showing good reproducibility of measurements. The exception is a pair of carbonate samples $(M+S)$ in which $S$ is 410 years younger than $M$ and 310 years younger than the average of all measurements. Our laboratory records showed that the amount of methane was not sufficient to fill the gas counter and inactive methane was added to the sample to bring it to the required filling pressure. The wrong pressure ratio was entered in the computer input data. The corrected result of sample $S$ yields an age of $3618 \pm 53 \mathrm{BP}$. Because of this error, all our analyses are based on the first result, $3290 \pm$ $50 \mathrm{BP}$, which was published in the first ICS report (Scott $e t$ al, in press).

A comparison of the mean value for the paired samples in Stages 1 and 2 with averaged measurements from all the laboratories (Table 1) shows the following: three pairs of samples are slightly younger than the average, and only one pair of carbonate samples $(C+L)$ is older than the average. Only one cellulose sample is within a quartile range and the other three pairs lie outside the quartile range but very close to its lower limits. 


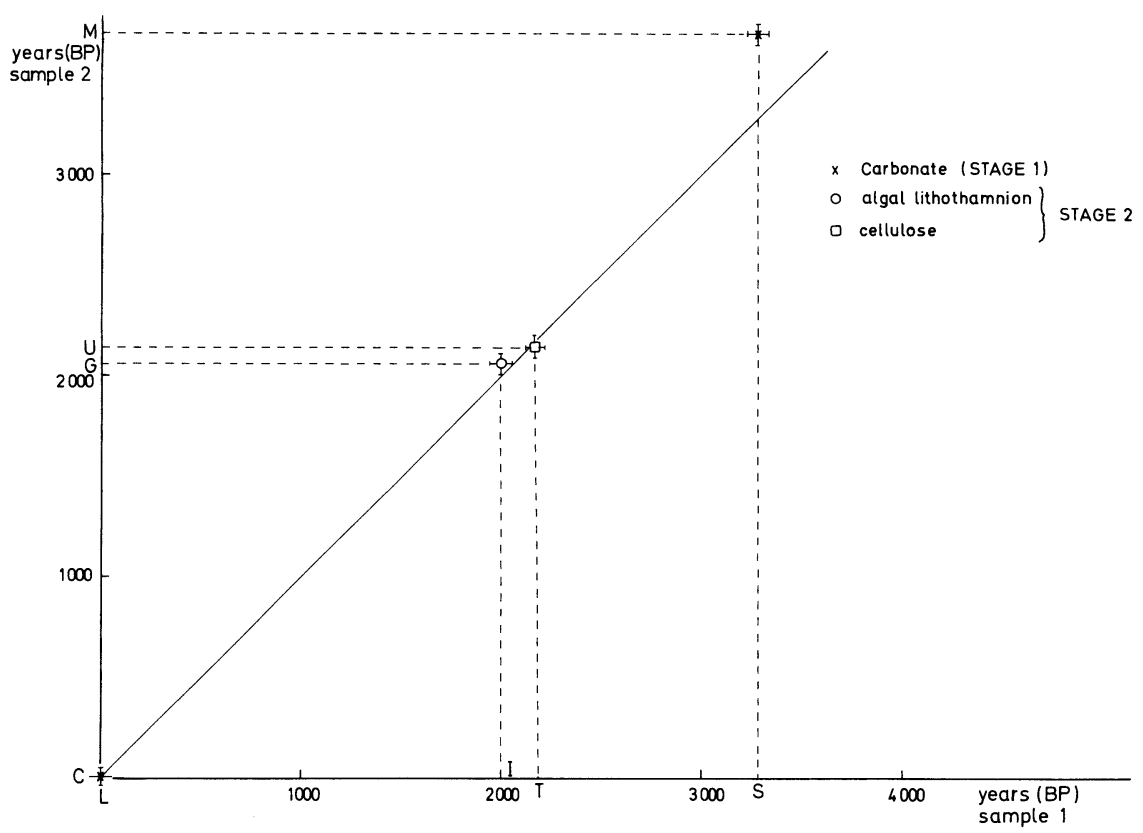

Fig 1. Zagreb ${ }^{14} \mathrm{C}$ results for duplicates, Stages 1 and 2

Stıge 3

In Stage 3, peat and wood samples were chemically pretreated but the shell samples were not. Results are in Tables 2 and 3 and in Figures 2 and 3. Figure 2 compares our results with the median value of all measurements (Scott et al 1989). Again, the good reproducibility of measurements are apparent (results of the paired samples are within 1o interval). All results are close to the ideal line of equality, however, slightly younger than the median.

The results of four wood samples agree well with equivalent ${ }^{14} \mathrm{C}$ ages derived from dendroages provided by the Belfast dendrochronological laboratory (Fig 3). Again, all samples are slightly younger, varying from -40 to -100 years from the median value. The measured age difference between samples $P$ and $Z$ ( $200 \mathrm{yr})$ agrees very well with the true age difference $(\approx 190 \mathrm{yr})$.

TABLE 2

Results of sample measurements from Stage 3 (in yr BP)

\begin{tabular}{|c|c|c|c|c|c|c|c|c|}
\hline \multicolumn{5}{|c|}{ Single samples } & \multicolumn{4}{|c|}{ Duplicate samples } \\
\hline \multirow{2}{*}{$\begin{array}{l}\text { Sample } \\
\text { code }\end{array}$} & \multirow{2}{*}{$\begin{array}{l}\text { Zagreb } \\
\text { results }\end{array}$} & \multicolumn{2}{|c|}{ ICS results } & \multirow[b]{2}{*}{ SD } & \multirow{2}{*}{$\begin{array}{c}\text { Zagreb } \\
\text { mean }\end{array}$} & \multicolumn{2}{|c|}{ ICS results } & \multirow[b]{2}{*}{ SD } \\
\hline & & Median & Mean & & & Median & Mean & \\
\hline \multirow{2}{*}{$\begin{array}{l}\text { B shell } \\
\text { I shell }\end{array}$} & $449 \pm 56$ & 658.5 & 601.3 & 180.4 & \multirow{2}{*}{494.5} & \multirow{2}{*}{670.0} & \multirow{2}{*}{636.5} & \multirow{2}{*}{176.0} \\
\hline & $540 \pm 56$ & 662.0 & 660.4 & 210.1 & & & & \\
\hline \multirow{2}{*}{$\begin{array}{l}\text { Y peat } \\
\text { E peat }\end{array}$} & $3288 \pm 66$ & 3375.0 & 3388.3 & 120.7 & \multirow{2}{*}{3336.5} & \multirow{2}{*}{3395.0} & \multirow{2}{*}{3388.3} & \multirow[b]{2}{*}{89.4} \\
\hline & $3385 \pm 67$ & 3380.0 & 3378.2 & 87.0 & & & & \\
\hline \multirow{2}{*}{$\begin{array}{l}\text { X } \text { wood }_{1} \\
\text { F } \text { wood }_{1}\end{array}$} & $2107 \pm 62$ & 2230.0 & 2228.5 & 115.1 & \multirow{2}{*}{2096.0} & \multirow{2}{*}{2218.5} & \multirow{2}{*}{2206.9} & \multirow{2}{*}{94.2} \\
\hline & $2085 \pm 61$ & 2202.0 & 2185.3 & 129.2 & & & & \\
\hline P wood 2 & $248 \pm 65$ & 300.0 & 297.1 & 154.3 & & & & \\
\hline $\mathrm{Z}$ wood $_{3}$ & $48 \pm 50$ & 120.0 & 111.2 & 155.4 & & & & \\
\hline
\end{tabular}


TABLE 3

Zagreb ${ }^{14} \mathrm{C}$ results (yr BP) and the calibrated age, the absolute age and the equivalent ${ }^{14} \mathrm{C}$ age ( $\mathrm{yr} \mathrm{BP}$ ) of wood samples from Stage 3

\begin{tabular}{lcccc}
\hline $\begin{array}{l}\text { Wood } \\
\text { sample }\end{array}$ & result & $\begin{array}{c}\text { Zagreb } \\
\text { calibrated age* }\end{array}$ & $\begin{array}{c}\text { Absolute age } \\
\text { (Belfast) }\end{array}$ & $\begin{array}{c}\text { Equivalent } \\
{ }^{14} \mathrm{C} \text { age }\end{array}$ \\
\hline $\begin{array}{l}\mathrm{X} \text { wood }_{1} \\
\mathrm{~F} \text { wood }_{1}\end{array}$ & $\begin{array}{c}2107 \pm 62 \\
2085 \pm 61\end{array}$ & $\begin{array}{c}346-71 \mathrm{BC} \\
(71 \%, 1 \sigma)\end{array}$ & $220-240 \mathrm{BC}$ & $\sim 2185$ \\
$\mathrm{P}$ wood $_{2}$ & $248 \pm 65$ & $\begin{array}{c}\mathrm{AD} 1521-1802 \\
(92 \%, 1 \sigma)\end{array}$ & AD 1521-1550 & $\sim 290$ \\
$\mathrm{Z}$ wood $_{3}$ & $48 \pm 50$ & $\mathrm{AD} 1805-1937$ & AD $1841-1870$ & $\sim 100$ \\
\hline
\end{tabular}

${ }^{*}$ According to Stuiver and Reimer (1986)

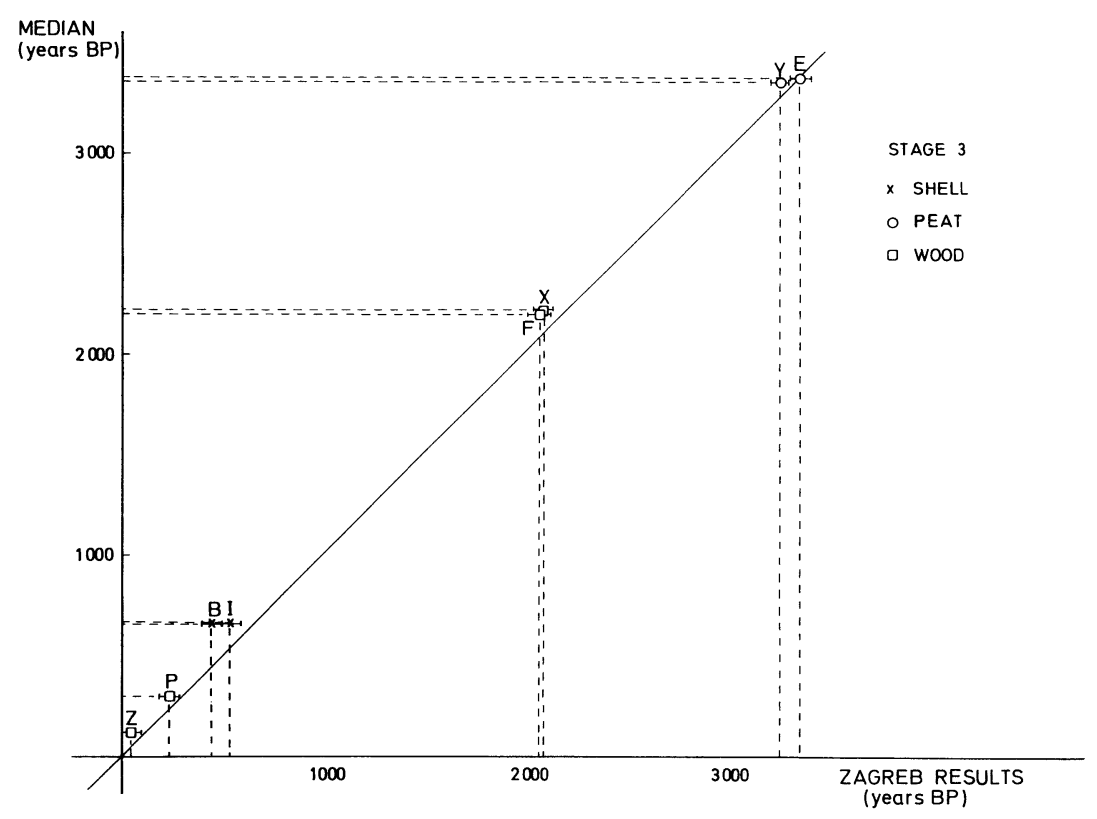

Fig 2. Comparison of the Zagreb ${ }^{14} \mathrm{C}$ results and the median value of all ICS measurements, Stage 3.

\section{CONCLUSION}

The results of our measurements in all three stages of the Glasgow International Collaborative Study show that most of our ${ }^{14} \mathrm{C}$ ages are slightly younger than the average or median values of all measurements. Figure 4 shows a histogram summarizing our results from all three stages, standardized to the median values. It is clear that our results lie within the interval $(30,-180)$ years from the median, or, on the average, 77 years lower than the ICS median values.

${ }^{14} \mathrm{C}$ activities of cellulose, wood and peat samples lie within a $1 \sigma$ error, and for the carbonate samples, within a $2 \sigma$ error from the ICS average or median values (Fig 4).

The results of paired samples show great internal consistency, $i e$, the differences between the duplicates agree with the claimed precision (except for one carbonate sample, as discussed above). 


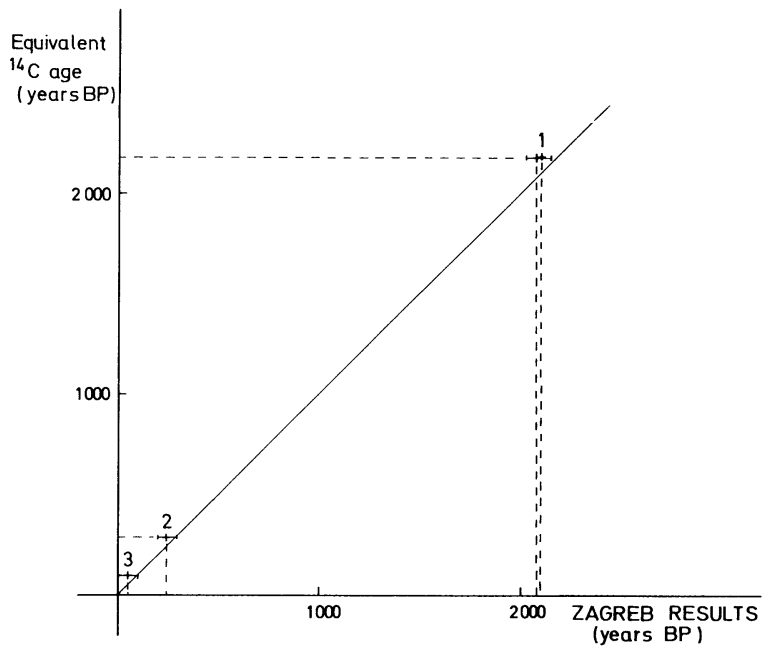

Fig 3. Comparison of wood samples, Stage 3: Zagreb ${ }^{14} \mathrm{C}$ results $v s$ equivalent ${ }^{14} \mathrm{C}$ ages derived from absolute ages.

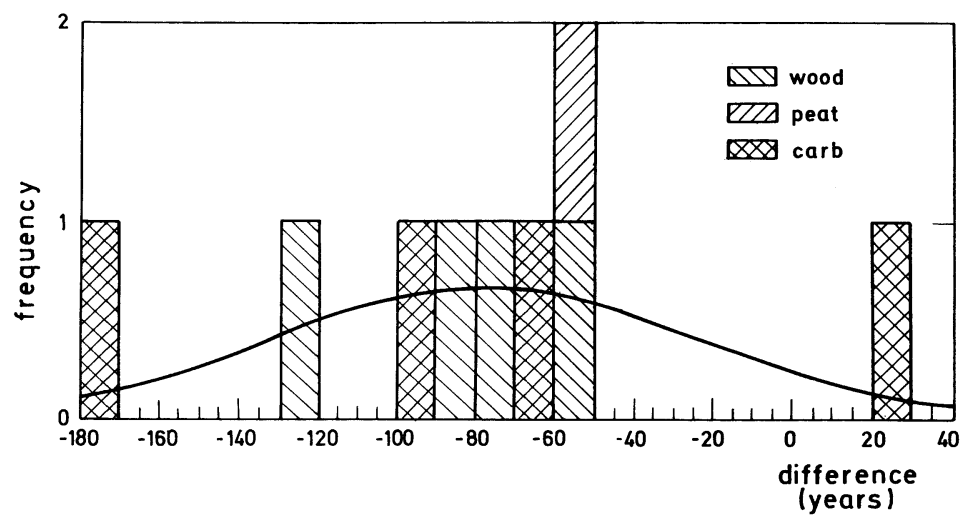

Fig 4. Frequency histogram of the difference between Zagreb ${ }^{14} \mathrm{C}$ results and the median values of ICS results for the corresponding sample. The curve represents fitted normal distribution with the mean value -77 .

The ICS was very useful and necessary for each participating radiocarbon laboratory. The choice of samples and good statistical data interpretation enabled each laboratory to control its own chemical preparation and counting system. Thus, we started to investigate the possible sources of error in sample preparation, calibration, counting procedure, etc, which render our dating slightly younger than the average ICS dating. We suggest the continuation of this kind of intercomparison.

\section{ACKNOWLEDGMENTS}

We would like to express our gratitude to the organizers of the ICS, especially to Marian Scott, Doug Harkness, Murdoch Baxter, Gordon Cook and Tom Aitchison, and our satisfaction with the excellent organization of this intercomparison. 


\section{REFERENCES}

Aitchison, TC, Scott, EM, Harkness, DD, Baxter, MS and Cook, GT 1990 Report on Stage 3 of the International Collaborative Program. Radiocarbon, this issue.

Obelić, B 1980 Computer analysis and interpretation of radiocarbon data. Fizika 12(2): 139-161. 1989 The radiocarbon data base at Rudjer Bošković Institute Radiocarbon Laboratory. In Long, A and Kra, RS, eds, Internatl ${ }^{14} \mathrm{C}$ conf, 13th, Proc. Radiocarbon 31(3): 1060-1065.

Obelić, B and Planinić, J 1977 Computer processing of radiocarbon and tritium data. In Povinec, P and Usačev, S, eds, Internatl conf on low-radioactivity measurement and applications, Proc. The High Tatras, Slovenske pedagogicke nakladatelstvo, Bratislava: 117-120.

Pearson, GW, Pilcher, JR, Baillie, MGL, Corbet, DM and Qua, F 1986 High precision ${ }^{14} \mathrm{C}$ measurement of Irish oaks to show the natural ${ }^{14} \mathrm{C}$ variations from $\mathrm{AD} 1840$ to $5210 \mathrm{BC}$. In Stuiver, $\mathrm{M}$ and $\mathrm{Kra}, \mathrm{RS}$, eds, Internatl ${ }^{14} \mathrm{C}$ conf, 12 th, Proc. Radiocarbon 28(2B): 911-934.

Scott, EM, Aitchison, TC, Harkness, DD, Baxter, MS and Cook, GT 1989 An interim progress report on Stages 1 and 2 of the International Collaborative Program. In Long, A and Kra, RS, eds, Internatl ${ }^{14} \mathrm{C}$ conf, 13th, Proc. Radiocarbon 31(3): 414-421.

Scott, EM, Baxter, MS, Harkness, DD, Aitchison, TC and Cook, GT, in press, Recent progress in the international calibration of radiocarbon laboratories. In Waterbolk, HT and Mook, WG, eds, Archaeology and ${ }^{14} \mathrm{C}$, Internatl symposium, 2nd, Proc. PACT.

Srdoč, D, Breyer, B and Sliepčević, A 1971 Rudjer Bošković Institute radiocarbon measurements I. Radiocarbon 13(1): 135-140.

Stuiver, M and Polach, HA 1977 Discussion: Reporting of ${ }^{14} \mathrm{C}$ data. Radiocarbon 19(3): 355-363.

Stuiver, M and Reimer, PJ 1986 A computer program for radiocarbon age calibration. In Stuiver, M and Kra, RS, eds, Internatl ${ }^{14} \mathrm{C}$ conf, 12th, Proc. Radiocarbon 28(2B): 1022-1030. 